Insisiva Dental Journal, Vol. 6 No.1 Bulan Mei Tahun 2017

\title{
Perbandingan Daya Hambat Ekstrak Daun dan Buah Belimbing Wuluh (Averrhoa bilimbi) Terhadap Bakteri Penyebab Gingivitis pada Pasien dengan Ortodontik Cekat The Comparison of Extract Starfruit Leaves and Fruits (Aver- rhoa bilimbi) Towards Bacteria of Gingivitis on Patient with Orthodontic Appliance
}

\author{
Ari Rahayu Widianingrum ${ }^{1}$, Nadianisa Marsha ${ }^{1}$, M. Shulchan \\ Ardiansyah ${ }^{2}$ \\ ${ }^{1}$ Mahasiswa Program Studi Kedokteran Gigi Universitas Muhammadiyah \\ Yogyakarta \\ ${ }^{2}$ Departemen Ortodontik Program Studi Kedokteran gigi, FKIK, Universitas \\ Muhammadiyah Yogyakarta \\ Korespondensi: ari.rahayu05@gmail.com
}

\begin{abstract}
Abstrak
Penggunaan alat ortodontik cekat di dalam mulut semakin meningkatkan retensi plak, yang apabila tidak ditanganimakaakan menimbulkan reaksi yang berkelanjutan seperti gingivitis. Ekstrak tanaman belimbing wuluh (Averrhoa bilimbi L) merupakan salah satu bahan antibakteri herbal yang dipercaya dapat menghambat pertumbuhan bakteri penyebab gingivitis.Daya antibakteri tanaman belimbing wuluh diperoleh dari kandungan zat aktifnya antara lain flavonoid, tanin, dan saponin. Penelitian ini bertujuan untuk menguji daya hambat ekstrak daun dan buah belimbing wuluh (Averrhoa bilimbi L) terhadap bakteri penyebab gingivitis pada pengguna ortodontik cekat. Desain penelitian pada penelitian ini adalah eksperimental laboratories murni secara in vitro dengan menggunakan metode difusi. Bakteri anaerob yang diperoleh dari swab pada cairan sulkus gingiva menggunakan paperpoint pada penderita gingivitis pengguna ortodontik cekat. Kelompok perlakuan dibagi menjadi masing-masing 6 kelompok yaitu 12,5\%, $25 \%, 50 \%, 100 \%$ konsentrasi ekstrak daun dan buah belimbing wuluh, aquades steril (kontrol negatif), khlorhexidin $0,2 \%$ (kontrol positif) dan direplikasi sebanyak 5 kali. Penelitian menggunakan media cawan petri dengan metode sumuran dan diinkubasi dengan $37^{\circ} \mathrm{C}$ selama $24 \mathrm{jam}$. Zona bening akan terlihat disekitar sumuran kemudian diukur menggunakan jangka sorong dengan satuan millimeter. Data yang diperoleh dianalisis dengan menggunakan uji One Way ANOVA kemudian dilanjutkan dengan Post Hoc LSD test. Hasil yang didapatkan pada penelitian ini menunjukkan bahwa ekstrak daun dan buah belimbing wuluh secara signifikan dapat menghambat pertumbuhan bakteri penyebab gingivitis $(\mathrm{p}<0,05)$.
\end{abstract}

Kata kunci: Bakteri gingivitis, ekstrak belimbing wuluh (Averrhoa bilimbi L), ortodontik cekat.

\footnotetext{
Abstract

The use of fixed orthodontic appliances in the mouth increase the retention of plaque, which if not treated it will cause continuous reaction such as gingivitis. Starfruit leaf and fruit extract (Averrhoa bilimbi L) is one of herbal antibacterial ingredients that are believed to inhibit the growth of bacteria that cause gingivitis. Antibacterial power is obtained from the leaves of starfruit active substance including flavonoids, tannins and saponins. The purpose of this study is
} 
Ari Rahayu Widianingrum, Nadianisa Marsha, M. Shulchan Ardiansyah | Perbandingan Daya Hambat Ekstrak Daun dan Buah Belimbing Wuluh (Averrhoa bilimbi) Terhadap Bakteri Penyebab Gingivitis pada Pasien dengan Ortodontik Cekat

to test the inhibition extracts of leaf and fruit starfruit (Averrhoa bilimbi L) against the bacteria that cause gingivitis in patient with fixed orthodontic appliance. The research design in this study were pure laboratory experimental in vitro by using a diffusion method. Anaerobic bacteria obtained from the swab in the gingival sulcus fluid using paper points in patients with fixed orthodontic appliance. The treatment group was divided into 6 groups: $12.5 \%, 25 \%, 50 \%$, $100 \%$ concentration of leaf and fruit extract starfruit, sterile aquades (negative control), chlorhexidine 0,2\% (positive control) and replicated 5 times. Research used the media petri dish studies with pitting and incubation method with $37^{\circ} \mathrm{C}$ for 24 hours. Clear zone will be seen around the wells was then measured using a caliper to millimeters. Data were analyzed using One Way ANOVA followed by a Post hoc LSD test. The result from this study isindicate that extracts of leaves starfruit can significantly inhibit the growth of bacteria that cause gingivitis $(p<0.05)$.

Keyword: Bacteria of gingivitis, extract of starfruit (Averrhoa bilimbi L), fixed orthodontics

\section{PENDAHULUAN}

Penggunaan alat ortodontik merupakan salah satu perawatan dari kesehatan gigi dan mulut. Perawatan ortodontik merupakan perawatan yang dilakukan di bidang kedokteran gigi yang bertujuan untuk mendapatkan penampilan dentofasial yang baik secara estetika yaitu dengan menghilangkan susunan gigi yang berdesakan, mengoreksi penyimpangan rotasional dan apikal dari gigi-geligi, mengoreksi hubungan antar insisal serta menciptakan hubungan oklusi yang baik ${ }^{1}$. Berdasarkan pemakaiannya, alat ortodontik dibedakan menjadi dua, yaitu ortodontik lepasan (removable) dan ortodontik cekat (fixed). Ortodontik lepasan adalah alat yang tidak menempel permanen pada gigi dan dapat dilepas sendiri oleh pasien. Ortodontik cekat adalah alat yang menempel secara langsung pada gigi. Alat ortodontik cekat mempunyai konstruksi yang lebih komplek dan sulit untuk dibersihkan dibanding dengan alat ortodontik lepasan, sehingga pengguna lebih sulit untuk menjaga kebersihan rongga mulutnya.

Adanya kegagalan dalam menjaga kebersihan rongga mulut ini dapat meningkatkan terjadinya akumulasi plak dan sejumlah lesi karies. Penggunaan alat ortodontik cekat di dalam mulut semakin meningkatkan retensi plak, yang apabila tidak ditangani maka akan menimbulkan reaksi yang berkelanjutan seperti gingivitis atau bahkan yang lebih parah yaitu periodontitis ${ }^{2}$.

Gingivitis merupakan proses peradangan bersifat reversibel di dalam jaringan periodonsium terbatas pada gingiva yang disebabkan oleh mikroorganisme yang membentuk suatu koloni serta membentuk plak gigi yang melekat pada tepi gingival. Bakteri penyebab gingivitis antara lain: Fussobacterium nucleatum, Prevotella intermedia dan Porphyromonas gingivalis. Pada umumnya gambaran klinis gingivitis ditandai dengan gingiva yang berwarna kemerahan, pembengkakan dengan konsistensi lunak, kecenderungan berdarah bila disentuh, serta terdapat plak dan kalkulus

Perawatan untuk penyembuhan gingivitis dapat dilakukan secara mekanik dan kimiawi. Perawatan secara mekanik dapat dilakukan scaling dengan cara menghilangkan tumpukan plak dan kalkulus. Secara kimiawi dapat diberikan obat kumur antiseptik dengan tujuan untuk membunuh bakteri-bakteri pasca perawatan secara mekanik. Obat kumur khlorhexidin, hexetidin, dan betadin merupakan contoh 
Insisiva Dental Journal, Vol. 6 No.1 Bulan Mei Tahun 2017

sediaan obat kumur yang beredar di pasaran. Khlorheksidin sebagai antiseptik yang dapat mencegah pembentukan plak dan perkembangan gingivitis. Khlorheksidin memiliki beberapa efek samping bagi rongga mulut dalam penggunaan jangka panjang, antara lain pewarnaan ekstrinsik gigi, tidak enak rasa di mulut, gangguan rasa, perubahan sensitivitas di lidah, rasa sakit dan iritasi karena kandungan alkohol ${ }^{3}$. Oleh karena itu dibutuhkan alternatif pengobatan lain yang lebih aman dan cukup terjangkau dari segi harga maupun cara memperolehnya.

Tanaman belimbing wuluh (Averrhoa bilimbi) merupakan salah satu tanaman obat di Indonesia yang mudah di temui dan memiliki khasiat menyembuhkan beberapa penyakit antara lain sebagai obat batuk, sariawan, gondongan, tekanan darah tinggi, gusi berdarah, sakit gigi berlubang ${ }^{4}$. Hasil penelitian Hayati, Sa'dah dan Lallis (2010) menyatakan ekstrak daun belimbing wuluh memiliki kandungan zat aktif di dalamnya yaitu tanin, flavonoid, saponin, peroksidase, kalsium oksalat, glucoside dan juga banyak mengandung vitamin $\mathrm{A}$, vitamin $\mathrm{B} 1$, serta vitamin $\mathrm{C}^{5}$. Buah belimbing wuluh (Averrhoa bilimbi) mengandung zat aktif flavonoid yang memiliki fungsi sebagai analgetik, antiinflamasi, antifungi, antivirus, diuretik, sedatif dan antibakteri. Flavonoid, tanin, dan saponin merupakan zat aktif yang dipercaya sebagai zat antibakteri. Selain itu Flavonoid dan saponin juga merupakan antiinflamasi ${ }^{6}$. Penelitian mengenai manfaat tanaman belimbing wuluh dalam kedokteran gigi menunjukkan bahwa ekstrak daun belimbing wuluh dalam berbagai konsentrasi mempunyai daya antibakteri terhadap pertumbuhan Streptococcus sanguis ${ }^{7}$. Pada penelitian lain juga terbukti bahwa ekstrak daun belimbing wuluh memiliki daya hambat terhadap pertumbuhan Streptococcus mutans ${ }^{8}$.

\section{METODE}

Jenis penelitian ini adalah penelitian eksperimental laboratoris dengan pendekatan post test only with control group design. Penelitian ini dilakukan di dua tempat, yaitu di Laboratorium Penelitian dan Pengujian Terpadu Universitas Gadjah Mada untuk pembuatan ekstrak dan Laboratorium Mikrobiologi Fakultas Kedokteran

Universitas Muhammadiyah Yogyakarta untuk uji daya hambat bakteri. Penelitian dilaksanakan pada bulan Februari 2017. Subyek penelitian ini adalah daun belimbing wuluh (Averrhoa bilimbi L) yang diekstrak dengan larutan etanol 70\% kemudian diencerkan menggunakan akuades untuk mendapatkan konsentrasi 12,5\%, 25\%, 50\% dan 100\%. Akuades steril sebagai kontrol negatif dan khlorhexidin sebagai kontrol positif.

Bakteri yang diujikan dalam penelitian ini adalah populasi bakteri pada penderita gingivitis pengguna ortodontik cekat yang dilakukan dengan cara pengambilan sampel cairan sulkus gingiva menggunakan 2 paper point steril yang dimasukkan di dalam area sub gingiva pada gigi dan didiamkan selama 20 detik. Ujung paper point yang telah diaplikasikan dari sulkus gingiva digunting sebatas meresapnya GCF pada paper point dengan gunting steril dan langsung dimasukkan dalam tabung reaksi yang berisi $3 \mathrm{ml}$ PBS.Sampel dalam PBS digetarkan menggunakan centrifuge dengan kecepatan 10.000rpm selama 30 detik. Setelah itu, $1 \mathrm{ml}$ sampel diencerkan dengan $9 \mathrm{ml}$ larutan aquadest dan dibuat 5 kali pengenceran. Larutan sampel 
Ari Rahayu Widianingrum, Nadianisa Marsha, M. Shulchan Ardiansyah | Perbandingan Daya Hambat Ekstrak Daun dan Buah Belimbing Wuluh (Averrhoa bilimbi) Terhadap Bakteri Penyebab Gingivitis pada Pasien dengan Ortodontik Cekat

yang telah diencerkan diambil sebanyak $1 \mathrm{ml}$ ditanam dalam media TSA lalu diinkubasi pada suhu $37^{\circ} \mathrm{C}$ selama 48 jam dalam anaerobic jar sehingga terjadi pertumbuhan koloni bakteri.

Satu koloni bakteri anaerob gram positif diambil dengan menggunakan ose steril dan dimasukkan ke dalam tabung yang berisi $\mathrm{NaCl}$ $1 \mathrm{ml}$, kemudian diinkubasikan lagi selama 2-4 jam pada suhu $37^{\circ} \mathrm{C}$. Kemudian, larutan dibuat suspensi sesuai standar brown III yaitu diencerkan dengan media BHI dengan digojok hingga kekeruhan $10^{8} \mathrm{CFU} / \mathrm{ml}$.

Setelah didapatkan standar konsentrasi bakteri, bakteri diambil dengan menggunakan kapas lidi steril dan dioleskan kepada permukaan media TSA secara merata. Kemudian, dibuat lubang sumuran sebanyak 3 lubang pada 1 cawan petri, dengan masing-masing berdiameter $5 \mathrm{~mm}$ dan kedalaman $3 \mathrm{~mm}$. Seluruh lubang diisikan konsentrasi ekstrak daun dan buah belimbing wuluh (Averrhoa bilimbi L) 100\%, 50\% , 25\% $, 12,5 \%$, aquades sebagai kontrol negatif dan khlorhexidin 0,2 \% sebagai kontrol positif. Langkah pengulangan sebanyak 5 kali. Setelah semua cawan petri sudah ditetesi ekstrak, kemudian inkubasi pada suhu $37^{\circ} \mathrm{C}$ selama 24 jam dalam anaerobic jar. Pengukuran zona radikal menggunakan jangka sorong dengan ketelitian $0,05 \mathrm{~mm}$.

Data yang sudah diperoleh kemudian di olah menggunakan SPSS for windows dilakukan uji normalitas dengan Saphiro-Wilk lalu uji homogenitas dengan Levene's test. Uji Kemaknaan menggunakan Uji Two Way ANOVA dengan derajat kepercayaan $95 \%(\alpha=0,05)$.

\section{HASIL PENELITIAN}

Penelitian untuk menguji kemampuan daya hambat ekstrak daun dan buah belimbing wuluh (Averrhoa bilimbi L) terhadap pertumbuhan bakteri penyebab gingivitis pada pengguna ortodontik cekat dengan melakukan pengukuran zona radikal yang terbentuk di sekitar sumuran yang telah dilakukan. Hasil pengukuran diameter zona radikal ekstrak daun dan buah belimbing wuluh pada masing-masing kelompok perlakuan dapat dilihat pada tabel berikut.

Tabel 1. Hasil uji aktivitas antibakteri ekstrak daun dan buah belimbing wuluh terhadap bakteri penyebab gingivitis pengguna ortodontik cekat

\begin{tabular}{ccc}
\hline Jenis Intervensi & Luas Zona Hambat & Normality Test \\
\cline { 2 - 3 } & Mean SD & -value \\
\hline Ekstrak Daun Belimbing Wuluh & & $0,794^{*}$ \\
\hline Konsentrasi 12,5\% & 4,45 & $0,962^{*}$ \\
\hline Konsentrasi $25 \%$ & 5,28 & $0,089^{*}$ \\
\hline Konsentrasi $50 \%$ & 6,06 & $0,905^{*}$ \\
\hline Konsentrasi $100 \%$ & 6,97 & $0,239^{*}$ \\
\hline Kkstrak Buah Belimbing Wuluh & & $0,243^{*}$ \\
\hline Konsentrasi $12,5 \%$ & 3,21 & $0,265^{*}$ \\
\hline Konsentrasi $25 \%$ & 3,92 & $0,105^{*}$
\end{tabular}

Keterangan:

*Shapiro-Wilk test: $p>0,05$; distribution data normal 
Tabel 1 memperlihatkan perbedaan luas zona daya hambat ( $\mathrm{mm}$ ) ekstrak daun daun dan buah belimbing wuluh (Averrhoa bilimbi) berdasarkan kosentrasi 12,5\%, 25\%, 50\% dan $100 \%$. Seperti yang telah dijelaskan sebelumnya, setiap kelompok konsentrasi menggunakan 5 sampel. Hasil penelitian memperlihatkan bahwa luas zona daya hambat terbesar ditemukan pada ekstrak daun belimbing wuluh dengan konsentrasi 100\% dan pada ekstrak buah belimbing wuluh dengan konsentrasi $100 \%$. Luas zona daya hambat konsentrasi $100 \%$ ekstrak daun belimbing wuluh mencapai $6,97 \mathrm{~mm}$, sedangkan luas zona daya hambat konsentrasi 100\% ekstrak buah belimbing wuluh mencapai $6,51 \mathrm{~mm}$. Adapun, luas zona daya hambat terendah ekstrak daun dan buah belimbing wuluh ditemukan pada kosentrasi $12,5 \%$, dengan luas zona daya hambat ekstrak daun belimbing wuluh hanya mencapai 4,45 $\mathrm{mm}$ dan luas zona daya hambat ekstrak buah belimbing wuluh mencapai 3,21 $\mathrm{mm}$.

Salah satu syarat penggunaan uji parametrik adalah uji Two Way ANOVA, maka data harus memiliki distribusi data normal.

Berdasarkan hasil uji normalitas, ShapiroWilk, diperoleh nilai $\mathrm{p}>0.05$, pada seluruh data kelompok. Hal ini menunjukkan bahwa distribusi data normal. Dengan demikian, uji parametrik, Two way ANOVA, dapat digunakan dalam penelitian ini.

Tabel 2. Hasil uji Two Way ANOVA

\begin{tabular}{lcrrrr}
\hline \multicolumn{1}{c}{ Source } & $\begin{array}{c}\text { Type III Sum of } \\
\text { Squares }\end{array}$ & df & Mean Square & F & Sig. \\
\hline Corrected Model & $59.770(\mathrm{a})$ & 7 & 8.539 & 16.313 & $.000^{*}$ \\
\hline Intercept & 1056.681 & 1 & 1056.681 & 2018.792 & $.000^{*}$ \\
\hline Jenis_Ekstrak & 12.133 & 1 & 12.133 & 23.180 & $.000^{*}$ \\
\hline Konsentrasi & 46.215 & 3 & 15.405 & 29.431 & $.000^{*}$ \\
\hline Jenis_-_Konsentrasi & 1.422 & 3 & .474 & .906 & $.449 *$ \\
Ekstrak*Ko & 16.750 & 32 & .523 & & \\
\hline Error & 1133.201 & 40 & & & \\
\hline Total & 76.520 & 39 & & & \\
\hline Corrected Total & & & & & \\
\hline
\end{tabular}

** $R$ Squared $=.781$ (Adjusted $R$ Squared $=.733$ )

Keterangan:

* Variabel (jenis ekstrak dan konsentrasi): p<0,05; signifikan, sedangkan varabel (interaksi jenis ekstrak dengan konsentrasi): $p>0,05$; tidak signifikan

** R Squared mendekati 1; korelasi kuat

Dari tabel di atas,nilai corrected model yaitu signifikansi (sig.) $<0,05$ sehingga pengaruh semua variabel independen (jenis ekstrak, konsentrasi dan interaksi jenis ekstrak dengan konsentrasi) secara bersama-sama terhadap variabel dependen (daya hambat) yaitu signifikan. Pada baris jenis ekstrak menjelaskan bahwa pengaruh jenis ekstrak terhadap daya hambat signifikansi (Sig.) $<0,05$ sehingga jenis ekstrak berpengaruh signifikan. 
Ari Rahayu Widianingrum, Nadianisa Marsha, M. Shulchan Ardiansyah | Perbandingan Daya Hambat Ekstrak Daun dan Buah Belimbing Wuluh (Averrhoa bilimbi) Terhadap Bakteri Penyebab Gingivitis pada Pasien dengan Ortodontik Cekat

Pada baris konsentrasi menjelaskan bahwa pengaruh konsentrasi terhadap daya hambat signifikansi (Sig.) $<0,05$ sehingga konsentrasi berpengaruh signifikan. Pada baris interaksi jenis ekstrak dengan konsentrasi menjelaskan bahwa pengaruh keduanya terhadap daya hambat signifikansi (Sig.) > 0,05 sehingga interaksi jenis ekstrak dan konsentrasi tidak berpengaruh signifikan. Nilai $R$ Squared determinasi berganda semua variabel independen dengan dependen. Pada tabel diatas nilainya adalah 0,781 yaitu mendekati 1, sehingga korelasi kuat.

Tabel 3. Perbedaan Rata-Rata Daya Hambat Ekstrak Daun dan Buah Belimbing Wuluh (Averrhoa Bilimbi)

\begin{tabular}{|c|c|c|c|c|}
\hline \multirow{2}{*}{ Jenis_Ekstrak } & \multirow{2}{*}{ Mean } & \multirow{2}{*}{ Std. Error } & \multicolumn{2}{|c|}{$95 \%$ Confidence Interval } \\
\hline & & & Lower Bound & Upper Bound \\
\hline Daun & $5.690 *$ & .162 & 5.361 & 6.020 \\
\hline Buah & $4.589 *$ & .162 & 4.259 & 4.919 \\
\hline
\end{tabular}

Keterangan:

* Rata rata daya hambat ekstrak daun dan buah belimbing wuluh setelah 4 kali perlakuan

Pada tabel diatas memperlihatkan bahwa rata-rata daya hambat ekstrak daun belimbing wuluh adalah 5,69 $\mathrm{mm}$ dan daya hambat ekstrak buah belimbing wuluh adalah 4,589 $\mathrm{mm}$, sehingga dapat disimpulkan bahwa dari hasil uji laboratoris ekstrak daun belimbing wuluh lebih efektif menghambat bakteri penyebab gingivitis. Namun secara uji statistik, interaksi antara jenis ekstrak dan konsentrasi tidak signifikan terhadap daya hambat.

\section{PEMBAHASAN}

Penelitian ini bertujuan untuk membandingkan daya hambat ekstrak daun dan buah belimbing wuluh (Averrhoa bilimbi $L)$ terhadap bakteri penyebab gingivitis pada pengguna ortodontik cekat. Hasil penelitian menunjukkan bahwa zona radikal terbesar ditemukan pada kontrol positif kemudian diikuti dengan zona radikal pada ekstrak 100\% kemudian diikuti dengan zona radikal pada ekstrak 50\% kemudian diikuti dengan zona radikal pada ekstrak $25 \%$ dan
$12,5 \%$. Terbentuknya zona radikal tersebut menunjukkan adanya daya antibakteri akibat zat-zat aktif yang terkandung di dalam ekstrak daun buah belimbing wuluh dan adanya efek bakteriostatik dari khlorheksidin, sedangkan sumuran berisi aquades steril tidak terbentuk area zona radikal karena aquades tidak memiliki daya antibakteri. Hasil penelitian diperoleh dengan mengukur diameter zona radikal yang terbentuk di sekitar lubang sumuran dengan menggunakan jangka sorong dengan satuan milimeter.

Hasil penelitian memperlihatkan bahwa luas zona daya hambat ekstrak daun belimbing wuluh jauh lebih besar dibandingkan ekstrak buah belimbing wuluh. Hal ini dapat dikarenakan kadar senyawa kimia yang terdapat dalam daun dan buah belimbing wuluh lebih tinggi sehingga menyebabkan perbedaan zona hambat.

Senyawa kimia tersebut antara lain golongan senyawa flavonoid, tanin, dan saponin. Flavanoid merupakan senyawa yang mudah 
larut dalam pelarut polar seperti etanol, butanol, dan aseton. Flavanoid golongan terbesar dari senyawa fenol, senyawa fenol mempunyai sifat efektif menghambat pertumbuhan virus, bakteri dan jamur. Senyawa ini dapat mencegah bakteri berada dipermukaan gigi.

Senyawa aktif flavonoid di dalam daun belimbing wuluh memiliki kemampuan membentuk kompleks dengan protein bakteri melalui ikatan hidrogen. Saat terjadinya kerusakan membran sitoplasma, ion $\mathrm{H}+$ dari senyawa fenol dan turunannya (flavonoid) akan menyerang gugus polar (gugus fosfat) sehingga molekul fosfolipida akan terurai menjadi gliserol, asam karboksilat dan asam fosfat. Hal ini mengakibatkan membran sitoplasma akan bocor dan pertumbuhan bakteri akan terhambat bahkan sampai kematian bakteri. Kerusakan pada membran sitoplasma mencegah masuknya bahan-bahan makanan atau nutrisi yang diperlukan untuk menghasilkan energi ${ }^{9}$.

Kandungan zat aktif lainnya yaitu tanin memiliki kemampuan menganggu metabolisme dan permeabilitas bakteri, akibatnya sel tidak dapat melakukan aktivitas hidup sehingga pertumbuhan bakteri akan terhambat bahkan mati. Aktivitas tanin sebagai antimikroba dapat terjadi melalui beberapa mekanisme yaitu menghambat enzim antimikroba dan menghambat pertumbuhan bakteri dengan cara bereaksi dengan membran sel dan menginaktivasi enzim-enzim esensial atau materi genetik. Selanjutnya, senyawa tanin dapat membentuk komplek dengan protein melalui interaksi hidrofobik sehingga dengan adanya ikatan hidrofobik akan tejadi denaturasi dan akhinya metabolisme sel terganggu.

Ekstrak daun dan buah belimbing wuluh
(Averrhoa bilimbi L) juga mengandung saponin. Saponin merupakan senyawa yang bersifat antibakteri dengan merusak membran sel bakteri. Membran sel berfungsi sebagai jalur keluar masuknya bahan-bahan penting yang dibutuhkan oleh sel. Apabila fungsi membran sel mengalami kerusakan akan mengakibatkan sel tersebut mati ${ }^{10}$.

\section{KESIMPULAN}

Berdasarkan hasil penelitian uji laboratoris, dapat disimpulkan bahwa ekstrak daun belimbing wuluh lebih efektif dibandingkan ekstrak buah belimbing wuluh. Hal ini dapat dilihat dari rata-rata zona daya hambat ekstrak daun belimbing wuluh yang lebih besar dibandingkan ekstrak buah belimbing wuluh. Namun berdasarkan hasil uji statistika, interaksi antara jenis ekstrak dan konsentrasi daun dan buah belimbing wuluh tidak signifikan terhadap daya hambat.

\section{SARAN}

1. Perlu dilakukan penelitian lanjutan dengan metode in vivo dan melakukan uji toksisitas pada hewan coba agar dapat digunakan sebagai obat herbal terstandar sebagai obat kumur.

2. Dilakukan uji klinis tentang khasiat antibakteri ekstrak daun dan buah belimbing wuluh sehingga dapat dijadikan alternatif sebagai obat kumur.

\section{DAFTAR PUSTAKA}

1. Dika, D. D., Hamid, T., \& Sylvia, M. (2011). Pengunaan Index of Orthodontic Treatment Need (IOTN) Sebagai Evaluasi Hasil Perawatan dengan peranti lepasan 
Ari Rahayu Widianingrum, Nadianisa Marsha, M. Shulchan Ardiansyah | Perbandingan Daya Hambat Ekstrak Daun dan Buah Belimbing Wuluh (Averrhoa bilimbi) Terhadap Bakteri Penyebab Gingivitis pada Pasien dengan Ortodontik Cekat

(The use of index of orthodontic treatment need (IOTN) as an evaluation of treatment with removable appliances. 2(1), 45-48.

2. Christensen, G. J. (2005). Special Oral Hygiene and preventive care for special needs. Journal American Dental Association, 136, 1141-1143.

3. Dekeyser, Desnyder, Pauwels, Quirynen, Soers, \& Van, S. (2005). A 0.05\% Cetyl Pyridinium Chloride $/ 0.05 \%$ Chlorhexidine Mouth Rinse During Maintenance Phase After Initial Periodontal Therapy. J Clin Periodontal Pubmed NCBI, 32(4), 390-400.

4. Muhlisah, F. (2000). Tanaman Obat Keluarga (TOGA). Jakarta: Penebar Swadaya.

5. Hayati, K. E., Fasyah, A. G., Sa'adah, \& Lallis. (2010). Fraksinasi dan Identifikasi Senyawa Tanin pada Daun Belimbing Wuluh (Averrhoa bilimbi L.). Jurnal Kimia, 193-200.

6. Sudarsono, Gunawan, D., Wahyono, S., Donatus, I. A., \& Purnomo. (2002).
Tanaman Obat II (Hasil Penelitian, Sifatsifat dan Penggunaan). Yogyakarta: Pusat Studi Obat Tradisional Universitas Gajah Mada.

7. Taliningrum, K. K. (2015). Perbedaan Berbagai Konsentrasi Ekstrak Etanol 70\% Daun Belimbing Wuluh (Averrhoa bilimbi L) Sebagai Bahan Obat Kumur Terhadap Hambatan Pertumbuhan Bakteri Streptococcus Sanguis in Vitro. Jurnal FKG Universitas Muhammadiyah Surakarta.

8. Apriliana N.S, M. (2013). Daya Hambat Ekstrak Daun Belimbing Wuluh (Averrhoa bilimbi Linn) terhadap pertumbuhan Streptococcus mutans. Jember: Bagian Mikrobiologi FKG Universitas Jember.

9. Liantari, D. S. (2014). Effect of wuluh starfruit leaf extract for Streptococcus mutans Growth. J majority, 27-33.

10. Ajizah, A. (2004). Sensitivitas Salmonella Typhymurium terhadap Ekstrak Daun Jambu Biji (Psidium guava L.). Bioscientiae, l(1). 